\title{
Editorial Introduction, Volume 2, February 2012
}

\author{
Hillegonda C. Rietveld
}

Editor

IASPM@Journal is the collaborative outcome of the many voices and approaches that make up the International Association for the Study of Popular Music. Much has happened since our first volume of 2010. During 2011, there has been an important change in the editorial organization that started when Editor and founder Martha Tupinambá de Ulhôa took on the duties of Chair of the IASPM Executive, and Héctor Fouce moved from an Editorial position to the Advisory Board to balance this with his commitments with IASPM.

During the General Meeting of the Editorial and Advisory Boards at the IASPM 2011 international conference, in South Africa, the decision was taken to appoint two new members to the Editorial Board. As a result, Advisory Board member Hillegonda Rietveld was selected as Editor; in addition, longstanding IASPM member Rupert Till joined the editorial team of Carlo Nardi, Geoff Stahl, Shane Homan and Michael Drewett. Later in that year, Michael left the Editorial Board to focus on other academic responsibilities. After seeing the journal through its first issues, Claudia Azevedo vacated the position of Assistant Editor, which is now taken up by Elina Hytönen. The journal also very much depends on the members of its Editorial Advisory Board, who are more than advisors when they take on the role of section editor for a specific article, as each represents specific IASPM branches and languages, from Japan to Brazil, and from France to New Zealand.

The journal has received a makeover from Carlo Nardi, with a new logo and also offers several new content features, such as our Special Issues and introductions to the diverse IASPM branches. The second volume of IASPM Journal, specially edited by Martha Ulhôa during her Visiting Research Fellowship at King's College, London, addresses the state of popular music studies in national and regional contexts, reflecting on the challenges in popular music studies. The contributions very much echo debates that took place the South African IASPM 2011 conference, which was devoted to the "many ways of situating popular music in the light of IASPM celebrating its 30th year". This issue, therefore, opens with an overview by Philip Tagg, co-founder of IASPM, kick-starting a critical argument that will hopefully inspire many of our member-readers to respond.

The contributions show a range of differentiated geographically located perspectives that nevertheless correspond to each other through a shared involvement with transnational networks, new forms of mediation and complex relationships with the all too often conservative cultural values of various academic institutions. Laura Jordán González and Douglas Smith give an introductory overview of Latin American popular music studies, teasing out the differences between Anglo and Latino contexts in understanding the 'popular' in popular music studies. John Collins provides the reader with an in-depth specific perspective from West Africa regarding the state of popular music studies at Ghanaian universities. This special edition is rounded off by historical overviews of popular music studies in Germany and Turkey, by Martin Pfleiderer and 
Ali Gedik respectively.

In addition to Special Issues, the journal maintains a space for ongoing research, scholarship and analysis in any genre of popular music, regardless of era or location. In this issue, we feature an Argentinean as well as an American analysis of local understanding of music genres in relation to nationalist politics. Berenice Maria Corti critically focuses on nationalism in the discourse of Argentine jazz studies, while Brian Holder presents a historical approach to the analysis of discourse by addressing ragtime music in relation to American perceptions of Russian immigrant culture during the years that followed the First World War. In addition, we showcase the energetic IASPM-US branch, with thanks to Rebekah Farrugia who recently joined our Advisory Board. To round off this issue, three book reviews, edited by Annti-Ville Kärjä, Chair of the IASPM Nordic branch, with Shane Homan.

Looking ahead, on behalf of the Editorial Board, we welcome our new Book Review Editor, Dr Sarah Baker. There will also be new additions to the Editorial Board, long-standing IASPM member William Echard, from Canada, and Simone Kruger, a German scholar abroad, both with extensive experience in editing academic journals in music studies. In our multi-lingual, inter-disciplinary and cosmopolitan diversity, we will move forward towards a special issue on technological, legal and cultural issues related to music copyright and digital mediation, which is planned for summer 2012.

For now, however, the Editorial Board wish to thank everyone who has devoted so much of their time and effort to make our new multi-textured special issue possible: the authors, the section editors, the reviewers, the copy editors. In particular, I thank our Special Editor, Martha Tupinambá de Ulhôa, who despite a busy schedule far from home, took her new colleagues under her wing to enable us to acclimatise to the journal's characteristics; Carlo Nardi, who tirelessly updated the journal site and its layouts; and Elina Hytönen, who patiently shaped up our brand new issue, Vol 2, State of the Nation: Review(s) of Popular Music Studies.

\author{
Enjoy, \\ Hillegonda
}

